\title{
YOUDEN'S TEST FOR CHROMATOGRAPHIC DETERMINATION OF ENALAPRIL IN PHARMACEUTICALS
}

Background. Robustness tests were firstly introduced for avoiding problems in interlaboratory studies and identifying the factors potentially responsible. A robustness test performing in late validation procedure involves the possibility that when the method is established not robust, it should be redeveloped and optimized. At this stage much effort has been made and money spent for optimization and validation, and therefore avoiding this would be great.

Objective. The aim of the study was to consider the robustness of HPLC determination of enalapril (in tablets) by the Youden's test.

Methods. Youden's test was chosen as an efficient method to assess the robustness among all analytical methods that is by means of an experiment design, which involved seven analytical parameters combined in eight tests. In previous studies, we evaluated the chromatographic method robustness to quantify enalapril (in tablets) by Youden's test.

Results. According to the Youden's test criteria, HPLC method proved to be greatly robust regarding the enalapril content in introduction of variation of seven analytic parameters. The lowest variation in enalapril content was $0.91 \%$, when Grace Platinump C8 EPS column (4.6 mm i.d. X $250 \mathrm{~mm}, 5 \mu \mathrm{m})$ was used. A holistic approach concerning simultaneous innovations in particle technology and instrument design was endeavored for the first time to meet and tackle the analytical laboratory issues. This was aimed at promoting success of analytical scientists as well as profitability and productiveness of business.

Conclusion. The Youden's test has been proved to be an efficient and useful tool for evaluation of robustness of enalapril HPLC assay.

KEY WORD: enalapril; high-performance liquid chromatography; robustness; quantitative analysis; Youden's test.

\section{Introduction}

Recently, Robustness testing is best known and most commonly used in the pharmaceutics because of the stringent regulations in the domain set by regulatory authorities that requires extensively validated methods. Therefore most definitions and existing methodologies, e.g. those from the $\mathrm{ICH}$, are found in the field, as stated before. Though, this has no implications for robustness testing of analytical methods in other domains and therefore this guideline is not confined to pharmaceutical methods [1].

Evaluation of robustness of chromatographic method is a laborious, complex and straining process, taking into account a great number of analytical parameters considered while carrying out the test. Some authors consider specific analytical parameters presenting small variaCorresponding author: Liliya Logoyda, PhD, DSc, Department of Pharmaceutical Chemistry I. Horbachevsky Ternopil National Medical University, 1 Maidan Voli, Ternopil, 46001, Ukraine.E-mail: logojda@tdmu.edu.ua tions in the nominal conditions; statistical analysis is made using the Student's $t$-test or ANOVA test. Other alternative for evaluation of robustness of analytical methods is the Youden's test. This test assesses not only the robustness of the method but also determines the each analytical parameter effect on final results. The main idea of the Youden's test is not studying one alteration at time but introducing several changes all together in this way that the effects of individual changes can be determined $[2,3,4]$.

Enalapril maleate is a maleate salt of enalapril, the ethyl ester of a long-acting angiotensin converting enzyme inhibitor, enalaprilat. Enalapril maleate is chemically defined as (S)-1-[N[1-(ethoxycarbonyl)-3-phenylpropyl]-L-alanyl]L-proline, (Z)-2-butenedioate salt (1:1). Enalapril, after hydrolysis to enalaprilat, inhibits angiotensin-converting enzyme (ACE) in humans and animals. ACE is a peptidyl dipeptidase that catalyzes the conversion of angiotensin I to the 
vasoconstrictor substance, angiotensin II. Angiotensin II also stimulates aldosterone secretion by the adrenal cortex. Enalapril in hypertension and heart failure beneficially effects primarily from suppression of the reninangiotensin-aldosterone system. Inhibition of ACE leads to decrease of plasma angiotensin II that results in decrease of vasopressor activity and decrease of aldosterone secretion [5].

The aim of the research was to determine the robustness of HPLC (High-Performance Liquid Chromatography) method for evaluation of enalapril by means of Youden's test, and define the analytical parameters that have greater influence on the final analysis.

\section{Methods}

Enalapril maleate was presented by Farmak pharmaceuticals (Kiev, Ukraine). HPLC grade acetonitrile, sodium dihydrophosphate dihydrate, phosphoric acid were got from Merck pharamaceticals.

\section{Instrumentation and chromatographic} conditions

Agilent 1260, Grace Platinump C8 EPS

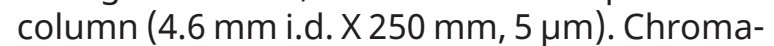
tographic separation was carried out at ambient temperature $\left(22-25^{\circ} \mathrm{C}\right)$. The compound was separated isocratically with a mobile phase consisting of acetonitrile and buffer solution $\mathrm{pH} 2.2(25 / 75, v / \mathrm{v})$, at a flow rate $2.0 \mathrm{~mL} / \mathrm{min}$ with injection volume $50 \mu \mathrm{L}$. Column temperature was $50{ }^{\circ} \mathrm{C}$. The effluent was monitored spectrophotometrically at a wavelength $215 \mathrm{~nm}$.

\section{Preparation of mobile phase}

To prepare buffer solution $\mathrm{pH} 2.2 .: 3.59 \mathrm{~g}$ of sodium dihydrophosphate dihydrate was dissolved in $1800 \mathrm{ml}$ of water, the $\mathrm{pH}$ of the solution was fixed with phosphoric acid to the value $(2.2 \pm 0.05)$, and then the volume of the solution with water $\mathrm{R}$ to $2000.0 \mathrm{ml}$ was added and mixed.

\section{Stock standard solutions}

$20 \mathrm{mg}$ of the standard sample of enalapril maleate was dissolved in a solvent, added $0.5 \mathrm{ml}$ of a solution of enalaprilat with a concentration of $0.4 \mathrm{mg} / \mathrm{ml}$ and $2.0 \mathrm{ml}$ of enalapril diketopiperazine solution at a concentration of $0.4 \mathrm{mg} / \mathrm{ml}$ was adjusted to a volume of $100.0 \mathrm{ml}$ with the same solvent.

\section{Procedures}

The standard solutions were prepared by dilution of the stock standard solution of mobile phase. Triplicate $50.0 \mu \mathrm{L}$ injections were made for each concentration and chromatographed under the conditions described above. The peak area of each concentration was plotted against the corresponding concentration to obtain the calibration graph and regression equation was computed [6].

\section{Results}

The robustness assessment of HPLC method for enalapril quantitation was performed by the method suggested by Youdene Steiner. For the nominal values of the method, seven analytical parameters were chosen and minor variations were induced. After, eight runs were completed in order to determine the effect of each parameter on the final result. The seven analytical parameters as well as the variations are presented in Table 1. The analytical circumstances of the nominal values are defined by capital letters and of the small variation - by lowercase letters.

The seven parameters and their respective variations were joined into eight assays or chromatographic runs randomly performed. The factorial combination of parameters for the Youden's test is presented in Table 2. The results of the analyses are defined by the letters

Table 1. Analytical parameters and variations for the robustness evaluation of HPLC method for enalapril quantitation

\begin{tabular}{|c|l|c|c|c|c|c|c|}
\hline \multicolumn{1}{|c|}{ Parameter } & \multicolumn{2}{c|}{ Nominal condition } & \multicolumn{3}{c|}{ Variation } \\
\hline $\mathrm{A} / \mathrm{a}$ & Acetonitrile in mobile phase & 25 & - & $\mathrm{A}$ & 35 & - & $\mathrm{a}$ \\
\hline $\mathrm{B} / \mathrm{b}$ & $\begin{array}{l}\text { Buffer solution pH } 2.2 \text { in mobile } \\
\text { phase }\end{array}$ & 75 & - & $\mathrm{B}$ & 65 & - & $\mathrm{b}$ \\
\hline $\mathrm{C} / \mathrm{c}$ & $\begin{array}{l}\text { pH of buffer solution in mobile } \\
\text { phase }\end{array}$ & 2.2 & - & $\mathrm{C}$ & 2.7 & - & $\mathrm{c}$ \\
\hline $\mathrm{D} / \mathrm{d}$ & Column temperature, ${ }^{\circ} \mathrm{C}$ & 50 & - & $\mathrm{D}$ & 40 & - & $\mathrm{d}$ \\
\hline $\mathrm{E} / \mathrm{e}$ & Mobile phase flow rate, $\mathrm{ml} / \mathrm{min}$ & 2.0 & - & $\mathrm{E}$ & 1.0 & - & $\mathrm{e}$ \\
\hline $\mathrm{F} / \mathrm{f}$ & Column supplier & $\begin{array}{c}\text { Grace } \\
\text { Platinump } \\
\text { C8 EPS }\end{array}$ & - & $\mathrm{F}$ & $\begin{array}{c}\text { Nucleosil } \\
\text { C18 }\end{array}$ & - & $\mathrm{f}$ \\
\hline $\mathrm{G} / \mathrm{g}$ & Chromatograph model & Agilent 1290 & - & $\mathrm{G}$ & HP 1100 & - & $\mathrm{g}$ \\
\hline
\end{tabular}


Table 2. Factorial combination of the analytical parameters for robustness evaluation

\begin{tabular}{|l|c|c|c|c|c|c|c|c|}
\hline \multicolumn{1}{|c|}{ Analytical parameter } & \multicolumn{9}{c|}{ Factorial combination } \\
\hline Acetonitrile in mobile phase & A & A & A & A & a & a & a & a \\
\hline $\begin{array}{l}\text { Buffer solution pH 2.2 in mobile } \\
\text { phase }\end{array}$ & B & B & b & b & B & B & b & b \\
\hline $\begin{array}{l}\text { pH of buffer solution in mobile } \\
\text { phase }\end{array}$ & C & c & C & c & C & c & C & c \\
\hline Column temperature & D & D & d & d & d & d & D & D \\
\hline Mobile phase flow rate & E & e & E & e & e & E & e & E \\
\hline Column supplier & F & f & f & F & F & f & f & F \\
\hline Chromatograph model & G & g & g & G & g & G & G & g \\
\hline Result & S & t & u & v & w & x & y & z \\
\hline
\end{tabular}

from $s$ to $z$. Hence, when combination 1 was assessed, the result was $s$, for combination 2 the result was $t$, and so on.

Three injections of each sample and stan dard solutions at the normal concentration were administered for each combination. A 30-minute pause for system stabilization took place after alteration of chromatographic column or mobile phase composition. In each combination the assessed results were for a peak area, retention time (Rt), tailing factor $(\mathrm{T})$, theoretical plates number $(\mathrm{N})$ and captopril content.

The following equation was used for evaluation of the effect of the column temperature on the final analyses results:

Effect $C / c=(s+u+w+y) / 4-(t+v+x+z) / 4 E q$

The Youden's test allows definite establishing of the parameters, which have a greater influence on the results of the analyses, and control more rigorously the eventual variations of these parameters that may arise during a routine analysis.

\section{Discussion}

In this research, the first trials were aimed to find optimal chromatographic conditions. The objective of the chromatographic method development was achievement of a peak tailing factor $<1.5$, retention time of between 4 and 5 minutes in consort with well resolution [7-17]. In both equipment (Agilent 1290 and HP1100), the analyses of the robustness evaluation of chromatographic method were carried out simultaneously. The results were attained in eight runs to enalapril sample and standard solutions.

The effects of the parameter variations on the analysis results are presented in Table 3.

By means of the Youden's test criteria, HPLC method proved to be significantly robust as regards the content of enalapril in case of introduced variations of seven analytical parameters [18]. The lowest variation in enalapril content was $0.91 \%$, when column Grace Platinump C8 EPS column $(4.6 \mathrm{~mm}$ i.d. $\times 250 \mathrm{~mm}, 5 \mu \mathrm{m})$ was used.

A holistic approach concerning simultaneous innovations in particle technology and instrument design was endeavored for the first time to meet and tackle the analytical laboratory issues. This was aimed at promoting success of analytical scientists as well as profitability and productiveness of business. The Platinum ${ }^{\mathrm{TM}}$ column advantage controlled silica exposure is the dissimilarity that makes Platinum ${ }^{\mathrm{TM}}$ columns unique. Instead of thorough covering of the silica with bonded phase to hide the silica, the exposure of the silica in Platinum ${ }^{\mathrm{TM}}$ columns is controlled to provide a dual mode separation

Table 3. Effects of the analytical parameters on content and retention time (Rt) for enalapril HPLC quantitation

\begin{tabular}{|l|c|c|}
\hline \multicolumn{1}{|c|}{ Effect } & Content (\%) & Rt (min) \\
\hline Acetonitrile in mobile phase & 0.15 & -0.26 \\
\hline Buffer solution pH 2.2 in mobile phase & 0.16 & -0.27 \\
\hline pH of buffer solution in mobile phase & 0.12 & 0.05 \\
\hline Column temperature & -0.05 & 0.05 \\
\hline Mobile phase flow rate & -0.03 & 0.05 \\
\hline Column supplier & 0.91 & -2.05 \\
\hline Chromatograph model & -0.04 & 0.11 \\
\hline
\end{tabular}


with both polar and non-polar sites exposed to the samples. This extends polar selectivity well beyond the other reversed-phase columns and gives separations that other columns cannot.

\section{Conclusion}

Youden's test proved to be an efficient and useful tool for the robustness evaluation of
HPLC method for assay of enalapril in pharmaceuticals. Therefore, Youden's test can be successfully used for the robustness evaluation for validation process of analytical methods.

\section{Funding}

This research received no external funding. Conflict of Interests

The author declares no conflict of interest.

\section{ЮДЕН ТЕСТ ХРОМАТОГРАФІЧНОГО ВИЗНАЧЕННЯ ЕНАЛАПРИЛУ В ЛІКАРСЬКИХ ЗАСОБАХ}

Вступ. Випробування на робасність спочатку були введені, щобуникнути проблем уміжлабораторних дослідженнях та виявити потенційно відповідальні фактори. Виконання перевірки надійності в кінці процедури валідації передбачає ризик того, що, коли виявиться, що метод не є надійним, його слід переробити і оптимізувати. На цьому етапі вже було витрачено багато зусиль і грошей на оптимізацію і перевірку, і тому хочеться цього уникнути.

Мета дослідження - визначити робасність хроматографічного визначення еналаприлу в таблетках з використанням тесту Юдена.

Методи дослідження. Ефективний метод оцінки надійності аналітичних методів за допомогою тесту Юдена шляхом розробки експерименту, який включає сім аналітичних параметрів, об'єднаних у восьми тестах. У дослідженнях ми оцінювали надійність хроматографічного методу для кількісного визначення еналаприлу в таблетках з використанням тесту Юдена.

Результати. Використовуючи критерії випробування Юдена, метод ВЕРХ показав високу надійність щодо вмісту еналаприлу при введенні варіації семи аналітичних параметрів. Найнижча зміна вмісту еналаприлу становила 0,91\%, коли використовувалася колонка Grace Platinumr C8 EPS-колони (4,6 мм i.d. Х 250 мм, 5 мкм). Вперше розроблено цілісний підхід, що передбачає одночасне впровадження інновачій у технології частинок та проектування приладів. Це було зроблено для того, щоб зробити вчениханалітиків більш успішними, а підприємства - більш прибутковими та продуктивними.

Висновки. Тест Юдена виявився ефективним і корисним інструментом для оцінки робастності для аналізу еналаприлу методом ВEPX.

КЛЮЧОВІ СЛОВА: еналаприл; високоефективна рідинна хроматографія; робасність; кількісний аналіз; Юден тест.

Відомості про автора

Логойда Лілія Святославівна - доктор фармацевтичних наук, доцент, завідувач кафедри фармацевтичної хімії Тернопільського національного медичного університету імені I.Я. Горбачевського, Тернопіль, Україна.

Information about the author

Logoyda L.S. - PhD, DSc, Head of Department of Pharmaceutical Chemistry I. Horbachevsky Ternopil National Medical University, Ternopil, Ukraine.

ORCID 0000-0002-5252-8806, e-mail: logojda@tdmu.edu.ua 


\section{References}

1. Faulon JL, Bender A. Handbook of chemoinformatics algorithms. CRC press; 2010 Apr 21:423. doi: 10.1201/9781420082999

2. Youden WJ, Steiner EH. Statistical analysis. Statistical manual of the association of official analytical chemists, Association of Official Analytical Chemists Arlington. 1975:33-83.

3. César ID, Pianetti GA. Robustness evaluation of the chromatographic method for the quantitation of lumefantrine using Youden's test. Brazilian Journal of Pharmaceutical Sciences. 2009 Jun;45(2):235-40.

doi: $10.1590 / S 1984-82502009000200007$

4. Karageorgou E, Samanidou V. Youden test application in robustness assays during method validation. Journal of Chromatography A. 2014 Aug 1;1353:131-9.

doi: 10.1016/j.chroma.2014.01.050

4. United States Pharmacopoeia (USP). Medicare Prescription Drug Benefit Model Guidelines Source Information. Available from: http://www.nlm.nih. gov. Accessed 13 Jan 2019.

5. Logoyda LI, Abdel-Megied AM, Kondratova YU, Trofimenko OL, Korobko D, Dakhym I. Development and validation of HPLC method for the simultaneous determination of enalapril maleate in present of their impurities: Application to tablet analysis. Int J Appl Pharm. 2018;10:98-102.

doi: 10.22159/ijap.2018v10i1.22805

6. State Pharmacopoeia of Ukraine: in 3 vol. State Enterprise "Ukrainian Scientific Center pharmacopoeia quality medicines". 2nd ed. Kharkiv: State Enterprise "Ukrainian Scientific Center of Quality pharmacopoeia of medicines"; 2014. p. 724.

7. State Pharmacopoeia of Ukraine. State Enterprise "Scientific and Expert Centre pharmacopoeia". $1^{\text {st }}$ ed. Appendix 2. Kharkiv: State Enterprise "Ukrainian Scientific Center of Quality pharmacopoeia of medicines"; 2008. p. 620.

8. Stanisz B. Evaluation of stability of enalapril maleate in solid phase. Journal of pharmaceutical and biomedical analysis. 2003 Feb 26;31(2):375.

doi: 10.1016/S0731-7085(02)00325-4

9. Santos EL, de Picoli Souza K, da Silva ED, Batista EC, Martins PJ, D'Almeida V, Pesquero JB. Long term treatment with ACE inhibitor enalapril decreases body weight gain and increases life span in rats. Biochemical pharmacology. 2009 Oct 15;78(8):951-8. doi: 10.1016/j.bcp.2009.06.018

10. Al-Omari MM, Abdelah MK, Badwan AA, Jaber AM. Effect of the drug-matrix on the stability of enalapril maleate in tablet formulations. Journal of pharmaceutical and biomedical analysis. $2001 \mathrm{Jul}$ 1;25(5-6):893-902

doi: 10.1016/S0731-7085(01)00399-5

11. Gu L, Strickley RG. A profound solvent effect on the diketopiperazine formation of the new dipeptide angiotensin-converting enzyme inhibitor, moexipril. International Journal of Pharmaceutics. 1990 Apr 30;60(2):99-107.

doi: 10.1016/0378-5173(90)90295-F

12. Stanisz BE. Kinetics of degradation of enalapril maleate in dosage forms. Acta Pol. Pharm. 2004;61:415-8.

13. Lima DM, dos Santos LD, Lima EM. Stability and in vitro release profile of enalapril maleate from different commercially available tablets: possible therapeutic implications. Journal of pharmaceutical and biomedical analysis. 2008 Aug 5;47(4-5):934.

doi: 10.1016/j.jpba.2008.02.030

14. Roškar R, Simončič Z, Gartner A, Kmetec V. Stability of new potential ACE inhibitor in the aqueous solutions of different $\mathrm{pH}$. Journal of pharmaceutical and biomedical analysis. 2009 Feb 20;49(2):295.

doi: $10.1016 / j . j p b a .2008 .11 .029$

15. Melander WR, Jacobson J, Horváth C. Effect of molecular structure and conformational change of proline-containing dipeptides in reversed-phase chromatography. Journal of Chromatography A. 1982 Jan 15;234(2):269-76.

doi: 10.1016/S0021-9673(00)81865-8

16. Mohan MA, Haider SZ, Anand AK, Srivastva AK. Validation of stability indicating HPLC method for the determination of enalapril maleate in tablet formulations. International Journal of Pharmacy and Pharmaceutical Sciences. 2011;3:180-3.

17. ICH Q2 (R1), Validation of analytical procedures, Text and methodology. International Conference on Harmonization, Geneva; 2005. p. 1-17. Available from: http://www.gmp-compliance.org/ guidemgr/files/Q2(R1).PDF Accessed 18 Jul 2019.

Received 01 September 2019; revised 23 October 2019; accepted 25 November 2019.

This is open access article distributed under the Creative Commons Attribution License, which permits unrestricted use, distribution, and reproduction in any medium, provided the original work is properly cited. 